\title{
The effect of PESTLE factors on development of e-commerce
}

\author{
Sy Thanh Phan ${ }^{a^{*}}$
}

\begin{tabular}{l}
${ }^{a}$ Academy of Journalism and Commu \\
\hline C H R O N I C L E \\
\hline Article history: \\
Received: September 9, 2020 \\
Received in revised format: Sep- \\
tember 9, 2020 \\
Accepted: November 6, 2020 \\
Available online: November 6, \\
2020 \\
\hline Keywords: \\
PESTLE factors \\
Development \\
E-commerce \\
Viet Nam
\end{tabular}

\section{A B S T R A C T}

\begin{abstract}
Over the past time, the dramatic growth of e-commerce has made Vietnam as one of the most potential markets in ASEAN. Vietnamese businesses as well as consumers are facing great opportunities from the industrial revolution 4.0. However, in addition to those significant developments, e-commerce in Vietnam also faces many challenges and barriers. Therefore, this research gives an overview of the current situation of e-commerce development and recommendations based on the findings of significant effect generating from PESTLE issues to further development of the online trading platforms in Vietnam.
\end{abstract}

(C) 2021 by the authors; licensee Growing Science, Canada.

\section{Introduction}

According to the 2018 White Book of E-commerce, recently released by the Department of E-Commerce and Digital Economy, the Ministry of Industry and Trade, in 2018, the entire e-commerce industry of Vietnam reached \$ 8.06 billion, up 30 percent compared to 2017, including goods and services. With the strength of a young population as well as a large proportion of smartphone users, the number of people making e-commerce transactions on smartphones is increasing. Vietnam is currently considered as one of the potential e-commerce markets with the fastest growth in the world.

Although there is a lot of potential for development, e-commerce in Vietnam still has obstacles as well as challenges in the development process (Nguyen \& Khoa, 2019). Currently, e-commerce is a newly developed field in Vietnam. In addition, this is also a very specific field, which is the combination of technology and market, which occurred parallelly in-between realistic and virtual factors, also existing and digital entities. Therefore, the legal framework in general still has many gaps that need to be completed. Therefore, completing policies and laws on e-commerce, building an ecosystem for e-commerce and digital economy is an important content that needs to be determined to orient e-commerce development in the near future (John, 2018). Besides, unhealthy competition between businesses also makes it difficult for businesses to participate in this market. Therefore, for e-commerce to develop in a healthy way, it is necessary to improve the legal environment through the enactment and enforcement of laws, as well as the governing commercial activities, adapting to international legal and practice on e-commerce transactions (Thu \& Nhung, 2019). 


\section{Literature Review}

The PESTEL model involves the collection and description of information about external factors that may or may affect your business (Nandonde, 2019). In addition, it is a simple and effective tool used in case analysis to identify external forces (macro environment level) that can influence an organization (Yatsenko \& Dmytriyeva, 2018). These forces can pose both an opportunity and a threat to an organization. PESTLE analysis is the most generic version of all PEST variants created. It is a very dynamic tool because new components can easily be added to to focus on one or another critical force influencing an organization (Kiong Yek, 2014). E-Commerce stands for Electronic Commerce. It refers to the activity of buying and selling a product or service over the internet. With the help of the internet, people can buy and sell almost anything, like books, electronics, clothes, software, and furniture. E-commerce provides a platform for people to buy or sell whatever they want, whenever they want. The e-commerce industry has seen tremendous growth in recent years and apart from some fluctuations in the global economy such as the bankruptcy process in Viet Nam, the situation is still favorable for the growth of the industry. Therefore, it can be seen that, there are not only technological and economics factors possessed the direct effect on the growth of e-commerce context, but also some existed components such as Political, Legal, Environment and social factors also contributing to that process. As a result, the following explanation will focus on PESTEL analysis of the e-commerce industry analyzes how these different forces can affect the e-commerce industry (Nandonde, 2019).

\subsection{Political factors (POL)}

The political and legal environment in the region or country is determined through government, public opinion, and consumer advocacy groups. The government needs to put in place a control measure to oversee internet development. But as the internet fosters global collaboration, government agencies across countries need to work together to ensure the safety of e-commerce transactions. Countries are examining the current tax structure to ensure that e-commerce activities do not reduce tax revenues of local governments and agencies (Nandonde, 2019). While the threats may not be the same as e-retailers like real retailers, there are some political hurdles before them. There are several risk factors that affect e-businesses (Uzoka \& Seleka, 2006). For example, for global leaders like Amazon and E-bay, growth in the Asia Pacific region could be hampered by Red tape. Several newsletters highlight how Red Tape in India can become the major difficulty in how new businesses try to expand their presence there. Political and regulatory challenges ahead of e-businesses have steadily increased (Coppel, 2000; Kabakova \& Plaksenkov, 2018; Gibbs, Kraemer, \& Dedrick, 2003; Rahayu \& Day, 2015). Overall, political issues can have a significant impact on e-commerce and its growth. As a result, the hypothesis is composed as:

\section{$\mathrm{H}_{1}$ : The Political factors directly affect the growth of E-commerce.}

\subsection{Economic factor (ECO)}

The overall economic development of the country will determine the frequency of e-commerce activities. Business organizations will target the developed economy for internet-based transactions more than a developing country. Globalization has encouraged the development of a single international market for commercial transactions. It has reduced social and cultural differences between countries. This has promoted a culture of standardizing prices and minimizing middlemen (Nandonde, 2019). Economic factors are of great significance to business activities. Whether it is an online or physical business, economic factors can have a significant effect on it. This is because economic factors are directly related to the business and their effect also directly on the revenue and profit of the business. Higher economic activity means faster growth and higher revenue for the e-commerce industry while lower economic activity means the opposite. In this way, economic factors can have a direct and profound impact in the e-commerce industry (Uzoka, Shemi \& Seleka, 2007; Scott et al., 2001; Zhu \& Thatcher, 2010)

From the above analysis, the hypothesis is composed as:

$\mathrm{H}_{2}$ : The economic factor directly affects the growth of E-commerce.

\subsection{Social Factor (SOC)}

Socio-cultural factors have profound effects on e-commerce. Among internet users, the biggest concern comes with privacy (Hwang, 2010). Privacy is described as an individual ethical right, benefiting from intrusion into their personal affairs. Internet users have an online identity through which they conduct financial and personal transactions (Liang et al., 2011). Consumers are very concerned with protecting this online identity (Lu, Fan, \& Zhou, 2016). In line with this, Countries are developing ethical laws that support proper use of the internet. Any organization should know about these laws and develop their marketing programs after carefully considering them. The increasing use of mobile technology has affected e-commerce. In most societies, mobile technology is already very common, and a larger number worldwide are now using mobile gadgets for shopping and other purposes. Socio-cultural factors also affect the business in other ways (Nandonde, 2019).

$\mathrm{H}_{3}$ : The social factor directly affects the growth of E-commerce.

\subsection{Technological factor (TECH)}

Modern digital technologies are developing in a breakthrough. It forces organizations to re-review their strategies more frequently (Klopping \& McKinney, 2004). The advent of the internet has seen the rise of online retailers, strongly influencing 
the functional role of traditional stores. The biggest challenge for today's business organizations is to access the current technology environment and find out which solution is best against the competition (Nandonde, 2019). The technological factor is very important in the context of the e-commerce industry (Chiemeke \& Evwiekpaefe, 2011). That is because the industry depends so much on technology. Everything is based on technology in electronics retail from sales to customer service. All e-commerce brands are in a race to stay ahead of their competitors in terms of technology. In this way, technology is a major influence on businesses and in this case e-commerce technology factors have a very special importance (Bendoly \& Kaefer, 2004).

\section{$\mathrm{H}_{4}$ : The technological factors directly affect the growth of E-commerce.}

\subsection{Environmental factor (EVN)}

Environmental factors also have a special importance in the context of the e-Commerce industry. While the industry's direct environmental impact is very low and almost zero, it still focuses heavily on sustainability. Brands like Amazon have invested heavily in the technology. Even in eCommerce, there are several areas where investing in sustainability can pay off. From sustainable packaging to minimizing waste and renewable energy, there are several areas where electronics retailers can invest in sustainability (Nandonde, 2019; Rahayu and Day, 2015).

\section{$\mathrm{H}_{5}$ : Environmental factor directly affects the growth of E-commerce.}

\subsection{Legal factor (LEL)}

Compliance is also important for businesses globally (Zhu, 2009). Any dispute with the law can be a costly affair and even eretail brands can be targeted if they are not interested in compliance (Nandonde, 2019). That is why major electronics retail brands have separate teams to handle legal matters. Failure to comply can lead to financial loss as well as loss of image and reputation. From labor laws to sustainability laws, there are several areas where e-retail brands must be careful in compliance (Shih and Kraemer, 2005). Furthermore, these laws vary from country to country to market to market and compliance in all areas is important. Therefore, in the case of companies operating under international law it can lead to great pressure and increase operating costs. Electronic retail brands must also be careful about applicable laws and comply (That, 2005).

\section{$\mathrm{H}_{6}$ : Legal factor directly affects the growth of E-commerce}

\section{Research Methodology}

\subsection{Data collection and Analysis}

The research uses a combination of two methods: (1) Qualitative research is done through the tool interviewing 37 e-commerce experts in different roles such as Solution Provider, Entrepreneur, and Director, Digital marketing manager, Online trader and officials of state management agencies on online transaction activities; (2) Quantitative research was done through direct surveys of 279 shop owners and online sellers in the city. The sampling method is a combination of germ development (for online shop owners) and a convenient random method (for online merchants). After getting the data, we have used the Exploratory Factor Analysis (EFA). Scale of trustful was judged by Cronbach's Alpha and the unsuitable variables were removed. The next step was to affirm the scale by analyzing confirmatory factor (Confirmatory Factor Analysis - CFA), the model trustful was judged by composite reliability, convergent validity and discriminant validity. Finally, we have analyzed theoretical model by structural equation modeling - SEM. Questions about business social responsibility factors include environment, honesty in business, workers, consumers and community engagement. All the questions in this part are based on the 5-point Likert scale (from 1 - completely disagree to 5 - completely agree), because it is often used to measure a set of statements of a concept.

\section{Research Findings}

Scale of the concepts of the proposed research model has been assessed by Cronbach's Alpha coefficient $(\alpha$ coefficient $) \geq 0.7$. The results have yielded the scales of POL (0.86), ECO (0.88), SOC (0.79), TECH (0.85), EVN (0.77), and LEL (0.84). All scaled have met the reliability requirements. As shown in Table 1 , the KMO coefficient $=0.87>0.5$ with the Bartlett Test significance level of 0.000 . Therefore, the EFA is consistent and the variables are related to each other for the entire data. In addition, the cumulative percentage of the eight factors that account for the variation of the data is $75.56 \%$. Finally, there are 6 factors (including 30 observed variables) with factor loads greater than 0.5 . So, the EFA has passed or all variables are valid for use as given in Table 1 .

Statistical indicators such as $\mathrm{X}^{2}=198.504, \mathrm{dF}=128 ; \mathrm{X}^{2} / \mathrm{df}=1.535<2, \mathrm{GFI}=0.921, \mathrm{TLI}=0.946, \mathrm{CFI}=0.955$ are greater than 0.9 , HOELTER $=184$, RMSEA $=0.048<0.05$ all proved that the model is considered appropriate to the data market. When the number of samples increases, these indicators are also raised. The results of non-normalization of the main parameters in the model show that, with $95 \%$ confidence, the causal relationships are statistically significant, because their values yield $\mathrm{p}<0.05$ (Table 2 ). 
Table 1

Validity result

\begin{tabular}{lllllll}
\hline Factors & POL & ECO & SOC & TECH & EVN & LEL \\
\hline & 0.86 & 0.83 & 0.83 & 0.81 & 0.78 & 0.88 \\
Factor loading & 0.86 & 0.83 & 0.83 & 0.79 & 0.75 & 0.85 \\
& 0.86 & 0.81 & 0.75 & 0.78 & 0.71 & 0.87 \\
& 0.74 & 0.81 & 0.99 & 0.74 & 0.73 & 0.79 \\
\hline
\end{tabular}

$\mathrm{KMO}=0.87>0.5$, Sig. of Bartlett Test is 0.000

$\%$ of variance $=75.56 \%$

Extraction Method: Principal Component Analysis.

Rotation Method: Varimax

Table 2

Results of causality between concepts in research model

\begin{tabular}{lllcc}
\hline Relationship & & Estimates & P-value \\
\hline E-growth & - & POL & 0.593 & 0.032 \\
E-growth & - & ECO & 0.334 & 0.000 \\
E-growth & SOC & TECH & 0.278 & 0.43 \\
E-growth & - & EVN & 0.188 & 0.000 \\
E-growth & - & LEL & 0.593 & 0.004 \\
E-growth & & & 0.187 & 0.000 \\
\hline
\end{tabular}

Thus, hypotheses $\mathrm{H} 1, \mathrm{H} 2, \mathrm{H} 4$ and $\mathrm{H} 5$ are accepted with $95 \%$ of confidence. While $\mathrm{H}_{3}$ is rejected because of the p-value which is greater than 0.05 .

\section{Conclusion and discussion}

This current study has identified a theoretical model to explain developments in the adoption and development of B2C ecommerce, which considers different types of determinants of this phenomenon. We have also evaluated the obtained model's validity for a particular context in Viet Nam.

From analyzing the current situation, the article gives some recommendations to further promote the development of e-commerce in Vietnam in the coming time.

- Government needs direct investment and incentive policies; attract investment from the society; private investment to develop technical infrastructure for electronic payment. Further step up the provision of public services, such as: e-customs; tax declaration and tax payment; do electronic import and export procedures. In addition, it is necessary to support businesses in distributing goods at home and abroad effectively with the lowest cost.

- Reasonable investment in building online stores, improving the quality of images and information in stores. This helps increase the competitiveness of businesses, because online stores help customers easily access the website of the business and quickly find what they are looking for, allowing businesses to investigate the tastes of customers. through statistics of purchases, visits

- Promoting investment in upgrading technology infrastructure, software, and hardware infrastructure, to ensure the safety of customer information and transactions, contribute to improve buyer's confidence in online activities, improve High brand image for business.

- Online retailers can also add ways to encourage customers to wait hard for slow delivery with less environmental damage, instead of promoting instant delivery and always to compete with each other. Manufacturers can also coordinate with retailers to get their goods shipped online to buyers using the original packaging, instead of having to add an extra layer of packaging from the online retailer.

- There are several types of socially acceptable and acceptable behavior around the use of the internet. These generally accepted standards are called ethical standards. Countries are developing ethical laws that support the right use of the internet. Any organization should know about these laws and develop their review programs after they are considered. 


\section{Acknowledgement}

The authors would like to thank the anonymous referees for constructive comments on earlier version of this paper.

\section{References}

Bendoly, E., \& Kaefer, F. (2004). Business technology complementarities: impacts of the presence and strategic timing of ERP on B2B e-commerce technology efficiencies. Omega, 32(5), 395-405.

Chiemeke, S. C., \& Evwiekpaefe, A. E. (2011). A conceptual framework of a modified unified theory of acceptance and use of technology (UTAUT) Model with Nigerian factors in E-commerce adoption. Educational Research, 2(12), 17191726.

Coppel, J. (2000). E-commerce: impacts and policy challenges.

Gibbs, J., Kraemer, K. L., \& Dedrick, J. (2003). Environment and policy factors shaping global e-commerce diffusion: A cross-country comparison. The information society, 19(1), 5-18.

Hwang, Y. (2010). The moderating effects of gender on e-commerce systems adoption factors: An empirical investigation. Computers in Human Behavior, 26(6), 1753-1760.

John, Y. (2018). A Comparative Study on the Precedents of E-learning Use of the Internet among S. Korea, Vietnam, and Singapore. Journal of Digital Convergence, 16(6), 1-8.

Kabakova, O., \& Plaksenkov, E. (2018). Analysis of factors affecting financial inclusion: Ecosystem view. Journal of business Research, 89, 198-205.

Kiong Yek, H. (2014). The Effects of Macroenvironment and Sociocultural Factors on the Marketing Strategy of RetailersA Case Study on AS Watson Pharmaceutical Stores in Malaysia and Taiwan (Doctoral dissertation, NSYSU).

Klopping, I. M., \& McKinney, E. (2004). Extending the technology acceptance model and the task-technology fit model to consumer e-commerce. Information Technology, Learning \& Performance Journal, 22(1).

Liang, T. P., Ho, Y. T., Li, Y. W., \& Turban, E. (2011). What drives social commerce: The role of social support and relationship quality. International journal of electronic commerce, 16(2), 69-90.

Lu, B., Fan, W., \& Zhou, M. (2016). Social presence, trust, and social commerce purchase intention: An empirical research. Computers in Human Behavior, 56, 225-237.

Nandonde, F. A. (2019). A PESTLE analysis of international retailing in the East African Community. Global Business and Organizational Excellence, 38(4), 54-61.

Nguyen, H. M., \& Khoa, B. T. (2019). A Study on the Chain of Cost Values-Online Trust: Applications in Mobile Commerce in Vietnam. Journal of Applied Economic Sciences, 14(1).

Rahayu, R., \& Day, J. (2015). Determinant factors of e-commerce adoption by SMEs in developing country: evidence from Indonesia. Procedia-social and behavioral sciences, 195, 142-150.

Scott, M. H., Hendrickson, C. T., \& Soh, D. L. (2001). Environmental and economic effects of e-commerce: A case study of book publishing and retail logistics. Transportation Research Record, 1763(1), 6-12.

Shih, C. F., Dedrick, J., \& Kraemer, K. L. (2005). Rule of law and the international diffusion of e-commerce. Communications of the ACM, 48(11), 57-62.

Tahat, H. (2005). Factors affecting E-commerce contract law. Britsh and Irish law, Education and technology Association, ppl-8.

Thu, T. M., \& Nhung, D. T. H. (2019). Empirical relationship among dimensions of customerbased brand equity in e-tailing service: a study in Vietnam context. Journal of International Economics and Management, 124, 3-23.

Uzoka, F. M. E., \& Seleka, G. G. (2006, June). B2C e-commerce development in Africa: case study of Botswana. In Proceedings of the 7th ACM conference on Electronic commerce (pp. 290-295).

Uzoka, F. M. E., Shemi, A. P., \& Seleka, G. G. (2007). Behavioral Influences on E-Commerce Adoption in a Developing Country Context. The Electronic Journal of Information Systems in Developing Countries, 31(1), 1-15.

Yatsenko, O. M., \& Dmytriyeva, N. O. (2018). Determinants of formation and development of international e-commerce. Actual problems of international relations, (135), 82-100.

Zhu, L. (2009, January). Legal and policy environments: An institutional perspective of global e-commerce adoption. In 2009 42nd Hawaii International Conference on System Sciences (pp. 1-10). IEEE.

Zhu, L., \& Thatcher, S. (2010). National information ecology: A new institutional economics perspective on global e-commerce adoption. Journal of Electronic Commerce Research, 11(1).

website

E-COMMERCE INDUSTRY IN VIETNAM - http:/www.ukabc.org.uk/wp-content/uploads/2018/09/EVBN-Report-E-commerce-Final-Update-180622.pdf 
(C) 2021 by the authors; licensee Growing Science, Canada. This is an open access article distributed under the terms and conditions of the Creative Commons Attribution (CC-BY) license (http://creativecommons.org/licenses/by/4.0/). 